INTERNATIONAL JOURNAL OF SYSTEMATIC BACTERIOLOGY

Vol, 20, No, 4 October 1970

pp. $519-533$

Copyright 1970, Iowa State University Press

\title{
CHARACTERS USED IN THE CLASSIFICATION OF LACTOBACILLI
}

Morrison Rogosa

Laboratory of Microbiology, National Institute of Dental Research National Institutes of Health, Bethesda, Maryland 20014

ABSTRACT. General conventional phenotypic characteristics differentiating species and groups of Lactobacillus are reviewed. Newer approaches to ta $\overline{x o n o m i c}$ studies, such as cell wall structure, metabolic pathways of substrate utilization, enzyme activity and homology or heterology of enzyme structure, are discussed. Experiments and problems in lysing highly resistant cells to obtain DNA and RNA for nucleic acid homology studies are described.

Historically, taxonomic investigations of the genus Lactobacillus have been. studies of phenotypic expressions by cell populations. Until recently, cell wall studies were not utilized in taxonomic schemes and studies of the genetic characteristics were non-existent or fragmentary. The classic scheme for taxonomic orientation stems from the work of Orla-Jensen $(1919,1943)$ and was extended and confirmed in its main outlines by Rogosa et al., (1953) and Rogosa and Sharpe (1959). The basic data and classification schemes derived from Rogosa et al. (1953) and Rogosa and Sharpe (1959), in which cell wall or genetic composition are not included, are presented in Tables $1-4$.

Studies of the biosynthesis, structure and function of cell walls and as sociated m.embranes are also concerned with phenotypic expressions and each of these facets of cell economy may be as dependent on environmental conditions and stresses as in many routine tests. For instance, sugar fermentations may vary dependent on the nutritional adequacy of the basal medium, anaerobiosis, etc. (Rogosa, et al., 1953). In the same way, cell wall biosynthesis and structure may be influenced by limitation of essential nutrients, such as lysine, diaminopimelic acid (DAP), etc., the presence of bacteriophage, or the action of such antibiotics as penicillin, vancomycin, cycloserine and similar substances in the inhibition of some essential step in cell wall synthesis. There are already some bits of suggestive evidence that nutritional inadequacies or imbalances may directly influence relative molar concentrations of cell wall constituents in Actinomyces (Pine and Boone, 1967).

Krulwich et al., 1967a.b. showed differences in rod and sphere stage cell walls of Arthrobacter crystallopoietes.

In a study of the lysis of certain group $\mathrm{N}$ streptococci by lysozyme and ethylenediaminetetracetic acid (EDTA) B rown et al., (1962) remarkably increased lysis and recovery of nucleic acids of Streptococcus diacetilactis by the simple expedient of growing the organism in media containing 2 per cent sodium citrate. McQuillen (1958), in a review on lysis resulting from metabolic disturbance, cited experiments with 
Table 1. Differential characteristics of heterofermentative lactobacilli.

\begin{tabular}{|c|c|c|c|c|c|c|c|c|c|c|c|c|c|c|c|c|c|c|}
\hline $\begin{array}{l}\text { Lactobact11us } \\
\text { Species }\end{array}$ & Colony & ${ }_{15 C}^{\text {Growth }}$ & & $\begin{array}{c}\text { Serological } \\
\text { group }\end{array}$ & $\mathrm{NH}_{3}$ & 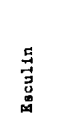 & $\begin{array}{l}\text { 吾 } \\
\text { 焉 } \\
\text { 尊 }\end{array}$ & 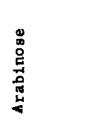 & 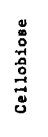 & $\begin{array}{l}: \\
\stackrel{\Delta}{0} \\
\stackrel{\Xi}{\Delta}\end{array}$ & 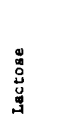 & 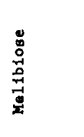 & 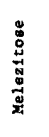 & 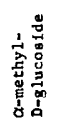 & 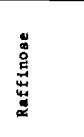 & 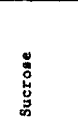 & 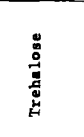 & 总 \\
\hline ferment 1 & R & - & + & F & + & - & - & $\begin{array}{l}-(79 x) \\
+(212)\end{array}$ & - & $\begin{array}{l}+(96 x) \\
W(4 \pi)\end{array}$ & $\underset{w(8 z)}{+(92 z)}$ & $\begin{array}{l}+(987)) \\
-(27)\end{array}$ & - & $\begin{array}{l}-(807) \\
+(207)\end{array}$ & $\begin{array}{l}+(988) \\
-(27)\end{array}$ & + & $\begin{array}{l}-(888) \\
+(122)\end{array}$ & $\begin{array}{l}-(80 z) \\
+(20 z)\end{array}$ \\
\hline brevis & $\mathrm{R}$ & + & - & z & + & + & - & + & - & $\begin{array}{l}+(40 z) \\
W(60 z)\end{array}$ & $\begin{array}{l}+(30 x) \\
W(70 \pi)\end{array}$ & + & - & $\begin{array}{l}+(887) \\
-(127)\end{array}$ & $\underset{W(338)}{+(67 x)}$ & $\begin{array}{l}+(887) \\
-(12 \pi)\end{array}$ & - & $\begin{array}{l}+(88 x) \\
-(128)\end{array}$ \\
\hline buchnert & $\mathrm{R}$ & + & - & E & + & + & - & + & - & + & $\underset{w(112)}{+(89 x)}$ & + & + & + & + & + & - & $\begin{array}{l}-(88 \pi) \\
+(14 \%)\end{array}$ \\
\hline celloblosus & $\mathrm{RDC}$ & \pm & - & & + & + & + & + & + & + & w & + & - & - & + & + & + & $\begin{array}{l}+(847) \\
-(167)\end{array}$ \\
\hline viridescens & R & + & - & & - & - & - & - & - & - & - & - & - & - & - & $\begin{array}{l}+(75 \pi) \\
-(25 z)\end{array}$ & $\begin{array}{l}-(80 z) \\
\text { or } y\end{array}$ & - \\
\hline
\end{tabular}

t- fermentation; \pm - variable; - - negatives $\mathrm{W}$ - veak; $\mathrm{a}$ - rough colony; RDC - rough, doughnut, or cauliflower-shaped colony. All produce $\mathrm{Dh}$ lactic ac1d.

significant quantities of $\mathrm{CO}_{2}$ and volatile acid. (45-50x) are produced from glucone. All ferment glucone, fructose, and maltose. None ferment adonitol, dextrin, dulc1tol, erythritol, glycerol, glycogen, 1nositol, tnulin, thamnose, sorbitol, sorbose, sterch, or $\alpha$-methyl-D-mennoside. Mannitol ls not fermented by $\underline{\underline{L}}$. ferment1 and 1. only rarely and weakly fermented by the other species. Salicin 18 not fermented except for occasional weak farmentations by $\underline{L}$. brevis and $\mathrm{L}$. cellobiosus. Mannose is fermented by $67 \%$ of $\underline{\mathrm{L}}$. fermenti stralns, occasionslly and weakly by $\underline{\mathrm{L}}$. celloblosub, and is not fermented by the other species. 
Table 2. Vitamin requirements of the nongas-forming lactobacilli.

\begin{tabular}{|c|c|c|c|c|c|}
\hline $\begin{array}{l}\text { Species of } \\
\text { Lactobacillus }\end{array}$ & Riboflavin & Pyridoxal & Folic Acid & Vitamin $B_{12}$ & Thymidine \\
\hline jugurti & + & + & - & - & - \\
\hline helveticus & + & + & - & - & - \\
\hline lactis & + & - & - & \pm & - \\
\hline bulgaricus & + & - & - & $=$ & - \\
\hline leichmannii & - & - & + & $\begin{array}{c}+ \\
\text { or } S\end{array}$ & - \\
\hline delbrueckii & + & - & - & - & + \\
\hline acidophilus & + & - & + & \pm & - \\
\hline salivarius & + & - & + & $=$ & - \\
\hline casei & + & $\begin{array}{c}+ \\
\text { or } S\end{array}$ & + & - & - \\
\hline arabinosus & $t^{*}$ & - & - & - & - \\
\hline pentosus & $=$ & - & - & - & - \\
\hline plantarum & - & - & - & - & - \\
\hline
\end{tabular}

$t=$ requirement; - = no requirement; + = variable and generally not required; $S$ = significantly stimulatory $t^{*}=$ variable, with melezitose $t$, mannoside $t$, glycoside - strains requiring riboflavin. All require

niacin and pantothenic acid. Thiamine is not required. Summary based on results of Rogosa et al. (1953), confirmed by Rogosa and Sharpe (1959) and Rogosa, Franklin and Perry (1961). Franklin and Sharpe (1964) with $L$. casei had a $91 \%$ correlation and with $L$. plantarum a $94 \%$ correlation with above results, even though a large number of their strains gave atypical fermentations. 


\begin{tabular}{|c|c|c|c|c|c|c|c|c|c|c|c|c|c|c|c|c|c|c|c|}
\hline $\begin{array}{l}\text { Lactobac1llus } \\
\text { spec1es }\end{array}$ & Colony & $\begin{array}{l}\text { Grov } \\
15 C\end{array}$ & $\begin{array}{l}\text { weh } \\
45 \mathrm{C}\end{array}$ & $\begin{array}{l}\text { Ac1d in } \\
\text { m11k (\%) }\end{array}$ & $\begin{array}{l}\text { Lactic } \\
\text { ac1d } \\
\text { Isomer }\end{array}$ & 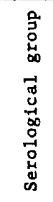 & 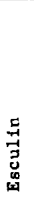 & 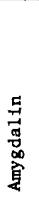 & 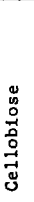 & 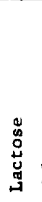 & 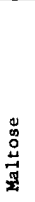 & 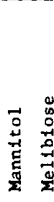 & 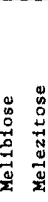 & 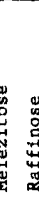 & & & 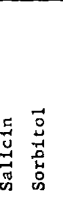 & $\begin{array}{l}0 \\
5 \\
5 \\
5 \\
5 \\
5\end{array}$ & 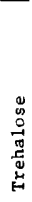 \\
\hline jugurt $\mathbf{i}$ & $\mathbf{R}$ & - & + & +2.75 & DL & A & - & - & - & + & - & - & - - & - & - & - & $-\quad-$ & - & - \\
\hline helveticus & $\mathbf{R}$ & - & + & +2.75 & DL & A & - & - & - & + & + & - & - & - & - & - & $-\quad-$ & - & $\mp$ \\
\hline lactis & $\mathbf{R}$ & - & + & +1.75 & $D(-)$ & $\mathbf{E}$ & $\mp$ & - & - & + & + & $-\quad-$ & - - & $-\quad-$ & - & - & +- & + & + \\
\hline bulgarlcus & $\mathbf{R}$ & - & + & 1.7 & $D(-)$ & $\mathbf{E}$ & - & - & - & + & - & $-\quad-$ & $-\quad-$ & - & - & - & - - & - & - \\
\hline le1chmannil & $\mathbf{R}$ & - & + & $0-0.1$ & $D(-)$ & $?$ & + & + & + & + & + & $-\quad-$ & $-\quad-$ & - & - & - & +- & + & + \\
\hline delbrueck11 & $\mathbf{R}$ & - & + & $0-0.05$ & $D(-)$ & $?$ & - & - & - & - & \pm & -- & $-\quad-$ & - & - & - & - & + & - \\
\hline actdoph1lus & $\mathbf{R}$ & - & + & s $0.3-1.9$ & DL & $?$ & + & + & + & + & + & $-\mp$ & $\mp-$ & $-\mp$ & $i$ & - & +- & + & + \\
\hline $\begin{array}{l}\text { sallvarlus var. } \\
\text { salfvarlus }\end{array}$ & $\mathbf{R}$ & - & \pm & 0.9 & $\begin{array}{l}L(+) \\
\text { and } \\
D L\end{array}$ & G & - & - & - & + & + & ++ & +- & -+ & + & + & -+ & + & + \\
\hline $\begin{array}{l}\text { salivarius var. } \\
\text { salicinius }\end{array}$ & R & - & \pm & 0.9 & $\begin{array}{l}\mathrm{L}(+) \\
\text { and } \\
D L\end{array}$ & G & + & - & - & + & + & ++ & +- & -+ & r & - & ++ & + & + \\
\hline casel var. casel & s & + & - & $1.2-1.5$ & $L(+)$ & $B, C$ & + & + & + & + & $t^{8}$ & +- & -+ & +- & 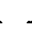 & - & + \pm & $t^{s}$ & + \\
\hline casel var. alactosus & $3 \mathrm{~s}$ & + & - & 0 & $L(+)$ & $\mathrm{B}, \mathrm{C}$ & + & + & + & - & $t^{8}$ & $+=$ & $=+$ & +- & . & - & + \pm & $t^{s}$ & + \\
\hline casel var. rhamnosus & $s \mathrm{~s}$ & + & + & $1.2-1.5$ & $L(+)$ & c & + & + & + & + & $t^{8}$ & +- & -+ & +- & 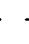 & + & ++ & $t^{s}$ & + \\
\hline plant arum & s & + & - & $0.3-1.2$ & DL & $\mathbf{D}$ & + & + & + & + & + & ++ & + \pm & \pm+ & + & + & + \pm & + & + \\
\hline
\end{tabular}


Legends for Table 3.

$t=$ fermentation with $\mathrm{pH}$ change of $1.5->2$ units; $t=$ variable results generally positive; $+=$ generally negative; $t^{s}=$ generālly slow fermẹntation. All strains $\vec{f}$ erment glucose; all except $\mathrm{L}$. leichmannii and $\mathrm{L}$. delbrueckii ferment galactose; fructose is fermented by all except $\bar{L}$. jugurti and L. helveticus which may ferment fructose slowly or weakly; all except L. jugurti, L. helveticus, and L. bulgaricus ferment mannose and negative, variable, or weak results may be obtained with these

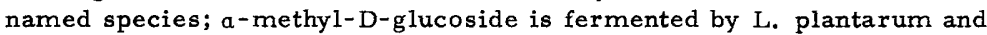
variably or weakly fermented by $L$. casei; a-methyl-D-mannoside is fermented only by some strains of L. plantarum. Adonitol and dulcitol are rarely fermented by lactobacilli; variable or weak fermentation may occur in L. casei; inulin and inositol are rarely fermented by lactobacilli and then weakly so; glycerol and starch are not fermented. Arabinose or xylose may be fermented only by $L$. plantarum. Sorbose may be fermented only by some strains of L. casei. Ammonia may be produced from arginine only by $\underline{L}$. leichmannii and $\underline{L}$. delbrueckii.

Table 4. Vitamin requirements of the heterofermentative lactobacilli.

\begin{tabular}{lccc}
\hline $\begin{array}{l}\text { Species of } \\
\text { Lactobacillus }\end{array}$ & Riboflavin & Pyridoxal & Folic Acid \\
\hline fermenti & - & - & - \\
buchneri & \pm & - & - \\
brevis & - & - & + \\
cellobiosus & - & - & - \\
viridescens & + & S & S \\
\hline
\end{tabular}

+ = requir ement; - = no requirement; $\pm=$ variable; $S$ = stimulatory .

All require niacin and pantothenic acid. Characteristically, all require thiamine in contradistinction to the homofermentative species. None require vitamin $B_{12}$ or thymidine. Summary based on Rogosa et al. (1953) and Rogosa and Sharpe (1959). Franklin and Sharpe (1964) agree that L. brevis requires folic acid, but only $52 \%$ of strains do not require riboflavin and only $11 \%$ do not require pyridoxal. Franklin and Sharpe (1964) find that only $37 \%$ of $\mathrm{L}$. buchneri are typical in not requiring folic acid pyridoxal. In genera $\overline{1}$ agreement with above summary and general contradistinction to Franklin and Sharpe (1964) are Abo-Elnaga and Kandler (1965) who found $88 \%$ of $\underline{L}$. brevis requiring and $89 \%$ of $\mathrm{L}$. buchneri not requiring folic acid; $88 \%$ of $\overline{\mathrm{L} \text {. brevis not requiring riboflavin and } 100 \%}$ not requiring pyridoxin; $100 \%$ of $\mathrm{L}$. fermenti not requiring folic acid and pyridoxin; but only $71 \%$ of L. fermenti did not require riboflavin. 
Streptococcus faecalis where rapid lysis ensued when lysine, a known cell wall component, was limiting. With limitations of amino acids not normally components of cell walls (such as valine) lysis did not occur even when growth was disturbed. Similar experiments with mutant strains of Escherichia coli, where either required lysine or DAP were limiting, also induced lysis because of defective cell wall formation. Lysis by bacteriophage and the exchange of nucleic acids with host cells obviously involve significant cell wall changes (Anderson, 1960; Jacob and Fuerst, 1958).

Nevertheless, under adequate conditions, there is probably sufficient constancy in cell wall structure because this knowledge generally correlates very well with other taxonomically useful characters. Cummins and Harris (1956) were the first to investigate cell walls of Lactobacillus, followed by Ikawa and Snell (1969) who studied strains of ten species. Their statement that the teichoic acids of Lactobacillus delbrueckii contained ribitol phosphate residues was erroneous because of a contaminated culture. Baddiley and Davison (1961) found only glycerol teichoic acid and Ikawa and Pettas (1963) later agreed with this and admitted that their earlier culture "was grossly contaminated with a coccus and, therefore, gave misleading results." A major contribution to the knowledge of cell walls of Lactobacillus has been made by Kandler and his co-workers (Kandler, 1967a, 1967b) (Plapp, Schleiffer and Kandler, 1967). Because of these studies, probably as much or more is known about the composition and cross-linking of amino acids and peptide bonds in the cell walls of Lactobacillus as in any other grampositive bacteria. Fortunately, this knowledge may be applied conjointly with a body of other meaningful and reliable information about Lactobacillus to clarify the status of groups and species of organisms within the genus.

My more recent concept of the general characteristics differentiating the major groups of Lactobacillus, namely, Thermobacterium Orla-Jensen 1919, Streptobacterium Orla-Jensen 1919, and Betabacterium Orla-Jensen 1919 is summarized in Table 5. This is the basic general scheme I am employing in the authorship of Lactobacillus for the forthcoming eighth edition of Bergey's Manual and is based on the study of all the strains submitted for consideration as type strains by the Subcommittee on Lactobacilli and closely related organisms of the International Committee on Nomenclature of Bacteria of the International Association of Microbiological Societies (1968). The se type strains, however, were only a part of the many additional strains whose characteristics permit this general grouping of the generic and sub-generic clusters of species already named in Tables $1-4$.

Cell wall data are not included in the Table 5 summation of subgeneric groups because such data are not necessary at this taxon level but appear to correlate very well with other species and subspecies characteristics. Kandler demonstrates this elsewhere in this symposium issue. The basic data concerning glucose and gluconate utilization, ribose fermentation, fructose 1, 6 diphosphate aldolase activity, and type of lactic dehydrogenase (LDH) are presented here in this unified way for the first time. The detailed characteristics of the various LHD enzymes will be presented elsewhere by Gasser whose work this is (manuscripts in preparation). 
Table 5. More general dffferentiating characteristics of Lactobacillus

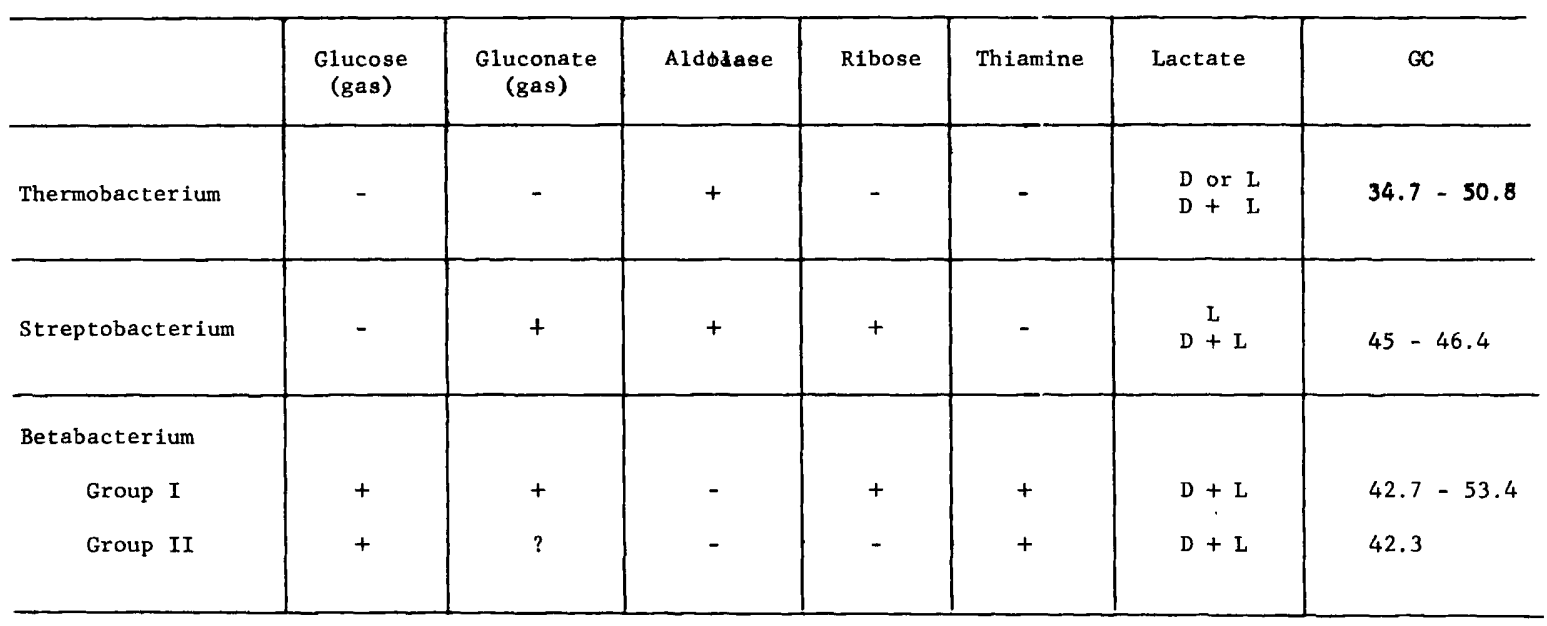


Until recently, very little knowledge of the genetic makeup of Lactobacillus was available and this information is still confined to guanine and cytosine moles per cent in the deoxyribonucleic acid, i.e., the GC content. Unfortunately, there were often significant differences in $\mathrm{GC}$ values cited in different publications for what was purported to be the same organism. In addition, all studies indicated a wide GC spread in Lactobacillus from about $33-53$ moles per cent of the DNA. Gasser and Mandel (1968) helped to resolve many difficulties when they showed that the variance of a number of GC values was due to unsatisfactory or different comparative methods. Nevertheless, the wide range of GC values for the Lactobacillus species was confirmed by them even when determined by an accurate cesium chloride gradient centrifugation.

The species of Propionibacterium have GC contents clustering closely about 67 per cent and there has been objection (Werner, 1966) to including the so-called "anaerobic corynebacterium" i.e., Corynebacterium acnes as Propionibacterium because of a different GC content. The present data, taken in context, indicate that this concept is too narrow and that within a genus there may be clusters of organisms with similar GC values but that there are also other clusters of organisms (species) with different GC values. However, all the species appear to have certain general similarities in morphology and metabolism, and are thus properly related in the next higher taxon, the genus.

Organisms with similar GC ratios in DNA may be as widely different as in human tissue and the pneumococcus - both with GC contents of about 39 per cent. There are obviously different arrangements of sequences of bases in their DNA. In other words, two organisms with similar GC percents are not necessarily of the same species, where two organisms with significantly differing GC content (probably greater than 2 per cent) cannot be of the same species, although this does not necessarily exclude them from the same genus.

For these reasons, more complete genetic knowledge requires information on the genetic homology of DNA and RNA from different organisms. Obviously, organisms with very different GC values would predictably have limited or no homology of repeating sequences of bases in their DNA or RNA.

In order to conduct such experiments, however, it is essential to isolate DNA. One population of cells is given radioactive thymidine, tritium, or other compounds incorporated into nucleic acids. These cells may be broken by mechanical means and the resultant isolated DNA is sheared to relatively small molecular sizes. Another cell mass is not radioactive and this DNA in any known agar block technique must be obtained relatively undegraded in as large molecular sizes as possible (Hoyer et al., 1964). To do this, however, requires that the cell is disrupted by mild, non-mechanical means.

Lactobacilli generally exhibit marked resistance to lysis and this, therefore, raises serious problems in obtaining unlabelled DNA for homology experiments. In an effort to find a successful technique for the gentle lysis of cells a large number of exploratory experiments were performed and these results may be summarized as follows:

(1) Unlike a number of gram-negative organisms, freshly grown or lyophilized cell powders of lactobacilli were not lysed by detergents such as sodium dodecyl sulfate; (2) Pronase B (a proteolytic 
enzyme preparation) plus sodium dodecyl sulfate were also ineffective and the unlysed cells when subjected to osmotic shock from L.5 M to $0.15 \mathrm{M}$ sucrose remained comletely unlysed; (3) cell powders were extracted with liquid phenol, the aqueous phase was separated and extracted seven times with ether, ether removed in a stream of nitrogen and an ultraviolet absorption spectrum was run from $260-280 \mathrm{~nm}$. There were no peaks in the entire range; indicating that no proteins, nucelotides or their degradation products had been extracted from the cells. Furthermore, on microscopic examination, the cells appeared remarkably normal although they were not viable.

Since penicillin is known to interfere with cell wall synthesis, Lactobacillus helveticus ATCC 15009, L. jugurti L 824, and L. bulgaricus A TCC 11842 were grown with penicillin G $(10,100$ and 1000 units $/ \mathrm{ml}$ ) in MRS broth. A large initial inoculum was employed and very little or any obvious growth (increase in optical density) was observed at any penicillin concentration. The cultures were examined microscopically at frequent intervals for six hours. L. jugurti appeared microscopically normal at all penicillin levels; $\underline{L}$. helveticus seemed normal at penicillin concentrations of 10 units $/ \mathbf{m l}$ but at 100 units $/ \mathrm{ml}$ numerous clubbed, often curved cells with fuzzy outlines and a few rounded (sphaeroplast-like) structures were seen. $\underline{\text { L. bulgaricus at } 10}$ or 100 units $/ \mathrm{ml}$ of penicillin presented numerous abnormal cells such as rods with blister-like protuberances, swollen cells, and numerous rounded structures with a stained central granule. At penicillin concentrations of 1000 units $/ \mathrm{ml}$, there were no intact rods, the cells appeared completely broken, but numerous sphaeroplast-like structures were still present. L. bulgaricus was unique among the three strains because it lysed completely overnight without further treatment, whereas $\underline{L}$. jugurti and $\underline{L}$. helveticus did not lyse at penicillin concentrations of 10 and 100 units $/ \mathrm{ml}$.

A second experiment with penicillin grown cells (using the general procedures of Marmur (1961) for the extraction of nucleic acids) was run as follows: A large inoculum of normal cells was incubated three hours (at least one logarithmic phase generation time) and penicillin ( 100 units $/ \mathrm{ml}$ ) was then added; cells were incubated another three hours; then centrifuged, and the recovered pellets were taken up in $0.10 \mathrm{M}$ EDTA plus $0.15 \mathrm{M} \mathrm{NaCl}, \mathrm{pH} 8$ and also in a second solution of the same composition but supplemented with 20 percent sucrose. The effect on the cells of lysozyme, trypsin, pronase, sodium dodecyl sulfate and combinations of these were studied. Sodium dodecyl sulfate alone or pronase alone or trypsin alone failed to lyse cells of $\underline{L}$. Lactis, $\underline{L}$. bulgaricus, $\underline{L}$. jugurti and $\underline{L}$. helveticus. Lysozyme plus detergent were required to lyse the se penicillin grown cells and trypsin was also required with L. helveticus ATCC 15009. The order of treatment required was lysozyme, trypsin, detergent. Lysis was often not obvious, until the addition of detergent and heating at $60 \mathrm{C}$ for 10 minutes. The disaggre gating effect of the detergent was then dramatic and sudden with complete lysis occurring within a few minutes. This type of experiment with penicillin grown cells was repeated with 19 strains representing $\underline{L}$.

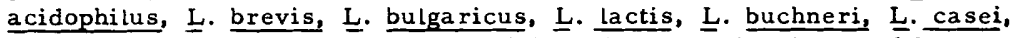

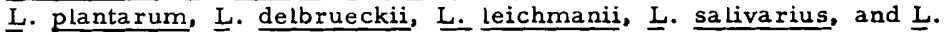
jugurti. Only certain strains of $\underline{L}$. bulgaricus and L. Lactis were easily lysed and it was in this experiment that the need for extraordinarily 
high levels of lysozyme was tentatively revealed. Most of the cultures were refractory to lysis. The refractory cultures were quick frozen in $\mathrm{CO}_{2}$ plus ethanol and then thawed quickly at $60 \mathrm{C}$ through ten such cycles without inducing any observable lysis.

Another similar experiment was performed with cells grown with vancomycin $(10 \mu \mathrm{g} / \mathrm{ml})$ and cycloserine $(100 \mu \mathrm{g} / \mathrm{ml})$. Except for two strains of $\underline{L}$. Lactis, none of 20 diverse strains was lysed.

The variability of various species toward lysozyme is shown in Table 6 . The species producing D-lactic acid were the most easily lysed by lysozyme when followed by trypsin and detergent treatment. Their characteristics have been presented in Tables 1 and 2. These organisms have GC moles percent of 50-50.8 (Gasser and Mandel, 1968) and their lactic acid dehydrogenases have similar electrophoretic mobilities in starch gels (Gasser, manuscripts in preparation). Although there are certain phenotypic differences, it may well be that $\underline{L}$. bulgari-

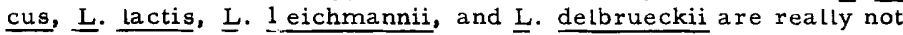
distinct species as they are presently conceived but are rather sub. species of a single species in the genetic sense. L. jugurti and $\underline{L}$. helveticus, producing DL lactic acid, are also probably not distinct species because a maltose fermentation by $\underline{L}$. helveticus is the only consistent phenotypic difference (Orla-Jensen, 1919) (Table 1). Although ther was some slight variation in lytic susceptibility, both species were lysed when 10 to $20 \mathrm{mg}$ of lysozyme were used, both have mean GC values clustering about 39 percent (Gasser and Mandel, 1968) and their $D$ and $L$ lactic dehydrogenases have identical electrophoretic mobilities in starch gels (Gasser, manuscript in preparation).

Of the remaining species, $L$. acidophilus and $\underline{L}$. salivarius were more resistant to the action of lysozyme and two to four times as much lysozyme was required to lyse these organisms as was the case with the D-lactic acid-producing strains. For instance, $20 \mathrm{mg}$ of lysozyme were required for complete lysis as compared to $2.5 \mathrm{mg}$ for the D lactic acid-producing strains. L. casei, $\underline{L}$. fermenti and $\underline{L}$. cellobiosus were very resistant to lysis by massive amounts of lysozyme when followed by trypsin and detergent treatments. Occasional strains exhibited some partial lysis, at best; however, undegraded DNA was never obtained. L. plantarum, L. brevis, and $\underline{L}$. buchneri were completely resistant to lysis by the se treatments.

The variant lytic action of lysozyme alone or when combined with other potentially lytic agents is not easy to explain. The primary enzymatic function appears to be as a $\beta-(1-4)$ glucosaminidase whereby cleavage occurs between the linkages connecting carbon 1 in $\mathrm{N}$-acetylglucosamine and carbon 4 in $\mathrm{N}$-acetylmuramic acid in the "bachone" structure of the cell wall (Salton, 1960; B lake, Mair et al., 1967; Blake, Johnson et al., 1967; Chipman et al., 1967; Chipman et al., 1968; Phillips, 1966; Rupley, 1967; Sharon, 1967). There are multiple binding sites in crystalline egg white lysozyme and this characteristic of the enzyme is discussed in detail in most of the immediately preceeding citations. It also appears that $\mathrm{N}$-acetylglucosamine and $\mathrm{N}$-acetylmura mic acid and saccharides closely related to lysozyme substrates may themselves act as competitive inhibitors (Blake, Johnson, et al., 1967; Sharon, 1967; Chipman et al., 1967). Thus, cell walls containing rela tively large numbers of backbone saccharide repeating units may quickly saturate available sites on the enzyme so that a sufficient number of 
Table 6. Comparative lytic effect of varying concentrations of lysozyme

\begin{tabular}{|c|c|c|c|c|}
\hline \multirow[t]{2}{*}{ Species } & & \multicolumn{3}{|c|}{ Milligrams of lysozyme } \\
\hline & 0.25 & 2.5 & 5 & 20 \\
\hline$\underline{\text { L. }}$ 1actis & + & + & + & + \\
\hline L. bulgaricus & + & + & + & + \\
\hline L. delbrueckii & \pm & + & + & + \\
\hline L. 1eichmannii & \pm & + & + & + \\
\hline L. jugurti & - & - & - & + \\
\hline L. helveticus & - & + & + & + \\
\hline L. acidophilus & - & - or & -ort & + \\
\hline ㄴ.ᅩ. salivarius & - & - & - & + \\
\hline$\underline{\text { L. }}$ case $\mathrm{i}$ & - & - & - & \pm \\
\hline L. plantarum & - & - & - & - \\
\hline$\underline{\text { L. cellobiosus }}$ & - & - & - & \pm \\
\hline L. brevis & - & - & - & - \\
\hline L. fermenti & - & - & - & \pm \\
\hline
\end{tabular}

* Quantities of crystalline egg white lysozyme (Sigma) were in $5 \mathrm{ml}$ EDTA $(0.1 \mathrm{M})+\mathrm{NaCl}(0.15 \mathrm{M}), \mathrm{pH} 8$, and initial cell suspensions adjusted to an absorbance of 1.0 at $660 \mu \mathrm{m}$. $+=$ at least a decrease of $80 \%$ in absorbance; \pm a decrease of less than $20 \%$ absorbance; and - no detectable decrease in àbsorbance. Lysozyme incubation was $37^{\circ} \mathrm{C}$ for $16 \mathrm{hr}$. followed by $25 \mathrm{mg}$ trypsin (Worthington $3 \mathrm{X}$ crystallized, in 50\% magnesium sulfate) for $2 \mathrm{hr}$, and finally by the addition of $0.25 \mathrm{ml}$ sodium dodecyl sulfate (sodium lauryl sulfate) to a final concentration of $2.5 \%$ and heating at $60^{\circ} \mathrm{C}$ for 10 min. Controls contained all ingredients except lysozyme. 
backbone cell wall units remain to maintain the general structural integrity of the wall. Conversely, walls containing significantly fewer backbone residues would not completely bind the available sites of a given amount of enzyme and therefore relatively less enzyme would be required to effect lysis. However, there is no existing evidence to substantiate this plausible line of argument.

Lysozyme has induced rough colonial variants and highly significant increases in cell length in $L$. casei but no information was given concerning possible changes in cell wall chemistry or structure (Takazoe et a L., 1962). Holden and Van Balgooy (1965) found that lysis of $\underline{L}$. plantarum by crystalline egg white muramidase varied markedly with physiological age and nutritional history of the culture. Cells taken during early exponential growth were readily attacked by the enzyme at $\mathrm{pH} 7.0$ and sensitivity to lysis declined steadily to relative resis tance of stationary phase cells. Such variation of sensitivity occurs also with $\underline{B}$. megaterium (Chaloupka et al., 1962). With suboptimal pantothenate, L. plantarum exhibited increased sensitivity to murami dase activity (Holden and Balgooy, 1965) with a correlating decrease in the O-acyl estex content of the cell wall. Such reduced O-acyl content has been associated with increased muramidase sensitivity (B rumfitt et al., 1958).

In our own experiments, we never succeeded in lysing whole cells of $\underline{L}$. plantarum even though young exponentially growing and penicillintreated cells were used. The buffer used in our experiments offers some disadvantages to lysozyme both in its metal sequestering function and the poising of $\mathrm{pH}$ at a value of 8.0. At $\mathrm{pH} 8.5$, of course, the activity of lysozyme drops sharply to an insignificant level. The conditions of our experiments were necessary, however, in order to inhibit the action of nucleic acid degrading enzymes which might otherwise make the isolation of DNA and RNA impossible.

Another lytic enzyme from Streptomyces albidoflavus (Tabata and Terui, 1962) (Gasser and Mandel, 1968) was used to lyse lactobacilli and it was no more successful than lysozyme in lysing lysozyme resis tant strains.

Evidence indicates that there are no differences in the species of Thermobacterium Orla-Jensen in the basic cell wall backbone, or in the murein or mucopeptide with its L-alanine, D-glutamic, L. lysine, D-alanine residues, or in the aspartic acid residues cross-linking the $\varepsilon$ amino group of tysine and the carboxyl group of the $D$-alanine of an adjacent peptide (Kandler, 1967a,b; Plapp et al., 1967). Also the teichoic acids of the Thermobacterium group are all of the glycerol phosphate type (Baddiley and Davison, 1961; Sharpe et al., 1964) and they appear to have the characteristics of group antigens (Sharpe, 1955; Sharpe et al., 1964). However, the organisms exhibited varying sensitivities to lysis.

Although it is still desirable to avoid undully harsh lytic procedures, large molecular sizes of nucleic acids are not as critically necessary in newer membrane filter techniques as in the previous agar block method. Thus, there is now more hope of obtaining experimentally satisfactory DNA. The genetic homology studies between the clusters of species (1) $\underline{L}$. bulgaricus, $\underline{\text { L. lactis, }} \underline{L}$. delbrueckii, $\underline{L}$. Leichmannii, and (2) $\underline{\text { L. }}$. jugurti and $\underline{L}$. helveticus are still necessary to establish their phylogenetic relationships and such experiments are being conceived for the near future. 


\section{REFERENCES}

Abo-Elnaga, 1.G . and O. Kandler, 1965. Zur Taxonomie der Gattung Lactobacillus Beijerinck. II Das Subgenus Betabacterium Orla -

Jensen. Zentr. Bakt. Parisiten. Abt. II. 119:117-129.

Anderson, T.F., 1960. Bacterial viruses - structure and function. 387-414. In the Bacteria I, ed. by Gunsalus and Stanier. Academic Press, N. Y.

Baddiley, J. and A. L. Davison. 1961. The occurrence and location of teichoic acids in lactobacilli. J. gen. Microbiol. 24:295-299.

Blake, C.C.F., G.A. Mair, A. C. T. North, D. C. Phillips, and V. R. Sarma. 1967. On the conformation of the hen egg-white lysozyme molecule. Proc. Roy. Soc. (London) Ser. B, 167:365-377.

, I. N. Johnson, G. A. Mair, A. C. T. North, D. C. Phillips, and V. R. Sarma. 1967. Crystallogxaphic studies of the activity of hen egg-white lysozyme. Proc. Roy. Soc. (London) Ser. B. 167:378-388.

Brown, W. C., W. E. Sandine, and P. R. Elliker. 1962. Lysis of lactic acid bacteria by lysozyme and ethylenediaminetetraacetic acid. J. Bacteriol. 83:697-698.

Brumfitt, W., A. C. Wardlaw, and J. T. Park. 1958. Development of lysozyme resistance in Micrococcus lysodeikticus and its association with an increased O-acetyl content of the cell wall. Nature $181: 1783-1784$.

Chaloupka, J., P. Kreckova, and L. Rihova. 1962. Changes in the character of the cell wall in growth of Bacillus megaterium cultures. Folia Microbiol. 7:269-274.

Chipman, D. M., V. Grisaro, and N. Sharon. 1967. The binding of oligosaccharides containing $\mathrm{N}$-acetylglucosamine and N.-acetylmuramic acid to lysozyme. J. Biol. Chem. 242:4388-4394.

and P. R. Schimmel. 1968. Dynamics of lysozyme-saccharide interactions. J. Biol. Chem. 243:3771-3774.

Cummins, C. S. and H. Haris. 1956. The chemical composition of the cell wall in some gram-positive bacteria and its possible value as a taxonomic character. J. gen Microbiol. 14:583-600.

Franklin, J. G. and M. E. Sharpe. 1964. Physiological characteristics and vitamin requirements of lactobacilli isolated from milk and cheese. J. gen Microbiol. 34:143-151.

Gasser, F. and M. Mandel. 1968. Deoxyribonucleic acid base composition of the genus Lactobacillus. J. Bacteriol. 96:580-588.

Hansen, P. A., Secretary. 1968. Type strains of Lactobacillus species. $89 \mathrm{pp}$. (A report by the taxonomic subcommittee on lactobacilli and closely related organisms of the International Committee on Nomenclature of Bacteria of the International Association of Microbiological Societies). American Type Culture Collections, Rockville, Maryland.

Holden, J. T. and J. N. A. Van Balgooy. 1965. Effect of nutritional and physiological factors on the reaction between Lactobacillus plantarum and muramidase. Biochem. Biophys. Res. Commun. 19:401-406.

Hoyer, B. H., B. J. McCarthy, and E. T. Bolton. 1964. A molecular approach in the systematics of higher organisms. Science 144:959-967. 
Ikawa, M. and E. E. Snell. 1960. Cell wall composition of lactic acid bacteria. J. Biol. Chem. 235:1376-1 382.

, and I. Pettas. 1963. Cell wall constituents of Lactobacillus delbrueckii. J. Bacteriol. 86:609-610.

Jacob, F. and C. R. Fuerst. 1958. The mechanism of lysis by phage studies with defective lysogenic bacteria. J.gen. Microbiol. 18: $518-526$.

Kandler, O. 1967a. Die chemische Zusammensetzung der Bakterienzellwand als Chemotaxonomisches Merkmal. Zentr. Bakt. Parisiten. Abt. I Orig. 205:197-210.

- 1967b. Taxonomie und technologische Bedeutung der Gattung Lactobacillus Beijerinck. Centr. Bakt. Parisiten. I Orig. Suppl. 2:139-164.

Krulwich, T.A., J. C. Ensign, D. J. Tipper, and J. L. Strominger, 1967. Sphere-rod morphogenesis in Arthrobacter crystallopoietes. I. Cell wall composition and polysaccharides of the peptidoglycan. J. Bacteriol. 94:734-740.

1967. Sphere-rod morphogenesis in Arthrobacter crystallopoietes. II. Peptides of the cell wall peptidoglycan. J. Bacteriol. 94:741-750.

Marmur, J. 1961. A procedure for the isolation of deoxyribonucleic acid from microorganisms. J. Mol. Biol. 3:208-218.

McQuillen, K. 1958. Lysis resulting from metabolic disturbance. J. gen. Microbiol. 18:498-512.

Orla-Jensen, S. 1919. The lactic acid bacteria. Mem. acad. roy. Sci., Danemark, Sect. Sci., 8 sér., 5:81-197, Andr. Fred. Host and Son, Copenhagen.

. 5:1943. The lactic acid bacteria. Ergänzungsband. Mém. acad. roy. sci. Danemark, Sect. sci. biol. $\underline{2}:(3): 1-145$, Ejner Munksgaard, Copenhagen.

Phillips, D. C. 1966. The three-dimensional structutire of an enzyme molecule. Sci. Am. 215:78-90.

Pine, L. and C. J. Boone. 1967. Comparative cell wall analyses of morphological forms within the genus Actinomyces. J. Bacteriol. $94: 875-883$.

Plapp, R., K. H. Schleiffer, and O. Kandler. 1967. The amino acid sequence of the mureins of lactic acid bacteria. Folia Microbiol. $12: 205-213$.

Rogosa, M., R. F. Wiseman, J. A. Mitchell, M. N. Disraely, and A. J. Beaman. 1953. Species differentiation of oral lactobacilli from man including descriptions of Lactobacillus salivarius nov. spec. and $\underline{L}$. cellobiosus nov. spec. J. Bacteriol. 65:681-699. and $M$. E. Sharpe. 1959. An approach to the classification of the lactobacilli. J. appl. Bacteriol. 22:329-340.

, J. G. Franklin, and K. D. Perry. 1961. Correlation of the vitamin requirements with cultural and biochemical characters of Lactobacillus spp. J. gen. Microbiol. 25:473-482.

Rupley, J. A. 1967. The binding and cleavage by lysozyme of Nacetylglucosamine oligosaccharides. Proc. Roy. Soc. (London) Ser. B, 167:416-428.

Salton, M. R. J. 1960. Surface layers of the bacterial cell. (97-151) In the Bacteria $I$, ed. by Gunsalus and Stanier. Academic Press, N. $Y$. 
Sharon, N. 1967. The chemical structure of lysozyme substrates and their cleavage by the enzyme. Proc. Roy. Soc. (London), Ser. B, $167: 402-415$.

Sharpe, M. E. 1955. A serological classification of lactobacilli. J. gen Microbiol. 12:107-122.

, A. L. Davison and J. Baddiley. 1964. Teichoic acids and group antigens in lactobacilli. J. gen Microbiol. 34:333-340.

Tabata, S. and G. Terui. 1962. Studies on microbial enzymes active in hydrolyzing yeast cell wall. I. Isolation of a strain and culture conditions for enzyme formation. J. Ferment. Technol. $\underline{40}: 366-373$.

Takazoe, I, T. Takeuchi and T. Nakamura. 1962. Rough variants of Lactobacillus casei by lysozyme treatment. The Bull. of Tokyo Dental College. $3: 1-13$.

Warner, H. 1966. The gram-positive nonsporing anaerobic bacteria of the human intestine with particular reference to the corynebacteria and bifidobacteria. J. appl. Bact. 29:138-146. 
